Int.J. Hum. Soc. Dev. Res.

ISSN (P):2521-1439; ISSN (E):2523-4331

Volume 3, № 2, 2019. 21-40

DOI:10.30546/2523-4331.2019.3.2.21

\title{
STRUCTURAL CHANGES AND DIVERSIFICATION OF AZERBAIJAN'S ECONOMY BY ENCOURAGING CHANCES FOR FRANCHISE: PROBLEMS AND OPPORTUNITIES
}

\section{Anar HASANOV}

\author{
(C) The Author(s) 2019
}

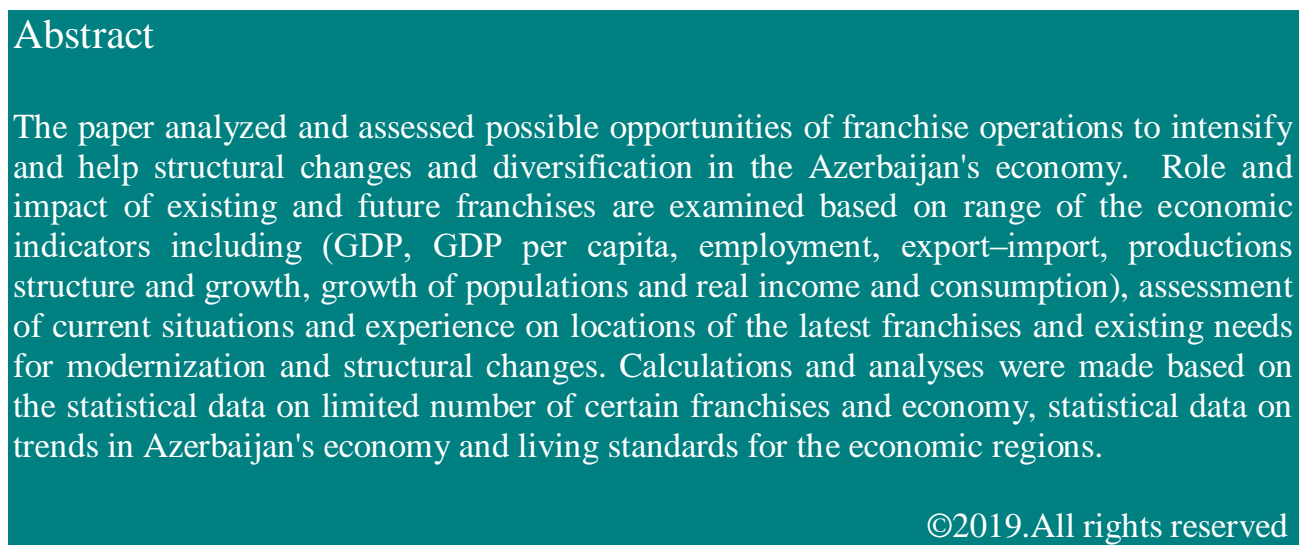

\section{ARTICLE HISTORY}

Received: $12 / 12 / 2018$

Accepted: 05/04/2019

Published online: 03/10/2019

\section{KEYWORDS}

Azerbaijan's economy, Franchises, Economic indicators of economic prosperity, restructuring and modernization; Export-import and franchise opportunities, Population and living standards 


\section{Introduction}

The main objective of the paper is to show the importance and possible role of franchises in the reconstruction and modernization of the economy of Azerbaijan. This study is organized around the key points which help to assess the current situation of the economy, content and structure of production, share of generated value added in GDP by types of economic activity, present figures on export and import, and range of relevant and valid indicators to assess the potential consumption differences across different economic regions.

The figures below constantly and logically show very clearly the conditionality and impact of living standards on the choices for the current and possible future locations of a potential franchise operation. The existing structure of GDP and production, and export and import figures shows huge dependence on mining and quarrying and oil industry. The main conclusions are based on official statistical figures of the State Statistical Committee and the relevant governmental bodies of the Republic of Azerbaijan, as well as other available resources, and interrelated calculations in growth and trends.

The text provides an overview of the literature, especially attitudes and opinions that indicate the significance and importance of franchise ventures towards changing, modernizing and restructuring of Azerbaijan's economy, as well as its diversification.

\section{Research Method}

For the purposes of data analysis (hypothesis testing), variables of GDP, production of goods or services, imports, exports, average earnings, population, and number of franchise facilities in a place or a specific area were observed. As to their measurement, variables as average earnings, GDP, production of goods or services, imports, exports are quantitatively continuous, while those of population and number of franchise objects are quantitative discrete, random variables. 
The main hypotheses are:

(1) Effective development and growth of the economy measured by GDP should be increased through industry sectors other than mineral fuels, minerals oils and their distillation products.

(2) It is possible to increase employment through franchises from various fields such as digitalization, e-commerce and e-business; small enterprise sectors - SMEs; Computer and IT; Tourism and Travel, and Real Estate.

(3) We can develop and increase the modern sectors of economy, such as secondary/manufacturing sectors which are concerned with producing finished goods, e.g. factories making toys, cars, food, and clothes, and especially service/'tertiary' sectors which offer intangible goods and services to consumers.

(4) It is good to open franchise facilities (food and beverage areas) along the routes of the three main roads leading from Baku to Iran by route E002, Baku to Georgia by route E60, and Baku to Russia by route E119.

This study used Azerbaijan's official statistics combined with calculations of relevant and valid trends using correlation analysis, relative indicators and percentage growth. Some sources are used to cover literature review in order to explain franchise contribution to modernization and diversification of the economy in middle developed countries.

\section{Azerbaijan - economic growth and needs for reconstruction and modernization}

OECD (2019) states that the main sectors of the economy are petroleum products, which account for over $90 \%$ of an export, the oil and gas industry that produces up to 33 and 55\% of the GDP, depending on oil prices. Economy of Azerbaijan heavily depends on the world's business cycle and oil prices. Table 1 shows that Azerbaijan's GDP Per Capita from 2013 to 2018 declines by $7.44 \%$ annually on average; also, exports declines by $14.22 \%$ on average and imports declined by $3.36 \%$ annually over the same period. In the coming years, this critical dependence on the world economic climate and oil prices will continue. Statista Logo (2019) forecasts that GDP Per Capita will show a slight increase in the coming 
period, and the expected GDP Per Capita will be: 2019 - \$4689,38; 2020 \$ 4718,93; 2021 - \$ 4795,52; 2022 - \$ 4941,44; 2023- \$ 5132,68; and 2024 $\$ 5350,32$. Still, everything depends on the world economy cycles and especially on oil prices.

Table 1. - The main economic indicators in Azerbaijan

\begin{tabular}{|l|l|l|l|l|l|l|}
\hline \multirow{2}{*}{ Indicators - \% } & \multicolumn{2}{|l}{ Years } \\
\cline { 2 - 7 } & 2013 & 2014 & 2015 & 2016 & 2017 & 2018 \\
\hline GDP & 5,8 & 2,8 & 1,1 & $-3,1$ & 0,1 & 1,4 \\
\hline GDP Per Capita & 5,06 & 0,20 & $-30,30$ & $-29,45$ & 6,68 & 13,84 \\
\hline Inflation & 2,4 & 1,4 & 4,0 & 12,4 & 12,8 & 2,3 \\
\hline Unemployment Rate & 4,97 & 4,91 & 4,96 & 5,04 & 5,04 & 5,03 \\
\hline $\begin{array}{l}\text { Current Account Balance } \\
\text { (\% of GDP) }\end{array}$ & 16,6 & 13,9 & $-0,4$ & $-3,6$ & 4,1 & 12,6 \\
\hline Exports & $-2,9$ & $-10,9$ & $-44,8$ & $-15,2$ & 14,7 & - \\
\hline Imports & $-0,9$ & $-11,0$ & 0,3 & $-7,4$ & 2,9 & - \\
\hline $\begin{array}{l}\text { Foreign Direct Investment } \\
\text { Flow -Inward }\end{array}$ & 31,3 & 68,3 & $-8,6$ & 11,2 & $-36,3$ & - \\
\hline $\begin{array}{l}\text { Foreign Direct Investment } \\
\text { Flow - Outward }\end{array}$ & 25,0 & 116,8 & 0,9 & $-21,0$ & $-0,4$ & \\
\hline
\end{tabular}

Source: Author calculations based on http://china-traderesearch.hktdc.com/business-news/article/The-Belt-and-RoadInitiative/Azerbaijan-Market-Profile/obor/en/1/1X000000/1X0A3IH1.htm, [Accessed: 26 October 2019], and https://www.macrotrends.net/countries/AZE/azerbaijan/gdp-per-capita, [Accessed: 27 October 2019]

Similar dependence and huge difference within Azerbaijan regional development are evident, especially in oil production. As can be seen in Table 2, the regions that produce the most natural gas are Aran with a share of $36 \%$, Baku city $33 \%$, followed by Absheron with a share of $13 \%$ of the total production. Thus, these cities, especially Baku, are the most developed and they attract almost $95 \%$ of the existing franchises. The huge challenge for authorities of Azerbaijan will be how and in which way to attract franchises to invest and operate in less developed regions. 
Table 2. Economic regions and natural gas production (thousand cubic meters) in the year 2018

\begin{tabular}{|l|l|l|l|}
\hline $\begin{array}{l}\text { Economic } \\
\text { region } \\
\text { code }\end{array}$ & $\begin{array}{l}\text { Economic region } \\
\text { names }\end{array}$ & $\begin{array}{l}\text { Natural gas (thousand } \\
\text { cubic meter) 2018 }\end{array}$ & Participation \\
\hline 01 & Absheron & 1.408 .480 & $13 \%$ \\
\hline 06 & Aran & 3.757 .472 & $36 \%$ \\
\hline 00 & Baku city & 3.401 .533 & $33 \%$ \\
\hline 09 & Daglig-Shirvan & 93.277 & $1 \%$ \\
\hline 02 & Ganja-Qazakh & 626.967 & $6 \%$ \\
\hline 04 & Lankaran & 272.133 & $3 \%$ \\
\hline 10 & Nakhchivan & 217.166 & $2 \%$ \\
\hline 05 & Quba-Khachmaz & 360.671 & $3 \%$ \\
\hline 03 & Sheki-Zaqatala & 258.798 & $2 \%$ \\
\hline 07 & Yukhari-Karabakh & 65.804 & $1 \%$ \\
\hline Total & & 10.462 .301 & $100 \%$ \\
\hline
\end{tabular}

Source: Author calculations based on https://www.azstat.org/portal/tblInfo/TblInfoList.do, [Accessed: 20 October 2019]

Alongside the above imbalances and differences, the economy of Azerbaijan is mostly driven by primary sectors (mining and quarrying, oil production, agriculture, and manufacturing) which contribute more than 48,3\%; secondary sectors contribute by $40,3 \%$. See, table 3 .

Table 3. Share of generated values added in GDP by the type of economic activity

\begin{tabular}{|c|c|c|c|c|c|c|c|c|c|}
\hline Indicator & 2010 & 2011 & 2012 & 2013 & 2014 & 2015 & 2016 & 2017 & 2018 \\
\hline $\begin{array}{l}\text { Production of } \\
\text { GDP - } \\
\text { Agriculture, } \\
\text { forestry and } \\
\text { fishing (percent) }\end{array}$ & 5,5 & 5,1 & 5,1 & 5,4 & 5,3 & 6,2 & 5,6 & 5,6 & 5,3 \\
\hline $\begin{array}{l}\text { Production of } \\
\text { GDP - Mining } \\
\text { and quarrying } \\
\text { (percent) }\end{array}$ & 45,9 & 48,0 & 43,1 & 39,2 & 34,3 & 26,4 & 30,7 & 34,2 & 38,3 \\
\hline
\end{tabular}




\begin{tabular}{|c|c|c|c|c|c|c|c|c|c|}
\hline $\begin{array}{l}\text { Production of } \\
\text { GDP - } \\
\text { Manufacturing } \\
\text { (percent) }\end{array}$ & 4,7 & 4,0 & 4,2 & 4,2 & 4,7 & 5,0 & 4,9 & 4,7 & 4,7 \\
\hline $\begin{array}{l}\text { Production of } \\
\text { GDP - } \\
\text { Electricity, gas, } \\
\text { stream } \\
\text { production, } \\
\text { distribution and } \\
\text { supply (percent) }\end{array}$ & 1,0 & 1,7 & 2,0 & 1,9 & 1,8 & 1,4 & 1,2 & 1,0 & 1,0 \\
\hline $\begin{array}{l}\text { Production of } \\
\text { GDP - Water } \\
\text { supply, waste } \\
\text { treatment and } \\
\text { disposal } \\
\text { (percent) }\end{array}$ & 0,1 & 0,1 & 0,1 & 0,2 & 0,2 & 0,2 & 0,2 & 0,2 & 0,2 \\
\hline $\begin{array}{l}\text { Production of } \\
\text { GDP - } \\
\text { Construction } \\
\text { (percent) }\end{array}$ & 8,1 & 8,0 & 10,1 & 11,6 & 12,6 & 12,0 & 10,5 & 9,6 & 8,0 \\
\hline $\begin{array}{l}\text { Production of } \\
\text { GDP - Trade: } \\
\text { repair of } \\
\text { transport means } \\
\text { (percent) }\end{array}$ & 6,4 & 6,3 & 6,7 & 7,1 & 7,9 & 9,9 & 10,3 & 10,4 & 9,6 \\
\hline $\begin{array}{l}\text { Production of } \\
\text { GDP - Transport } \\
\text { and storage } \\
\text { (percent) }\end{array}$ & 5,6 & 5,1 & 4,9 & 4,4 & 4,5 & 6,0 & 6,7 & 6,7 & 6,3 \\
\hline $\begin{array}{l}\text { Production of } \\
\text { GDP - } \\
\text { Accommodation } \\
\text { and food service } \\
\text { activities } \\
\text { (percent) }\end{array}$ & 1,0 & 1,4 & 1,6 & 1,8 & 2,1 & 2,4 & 2,4 & 2,4 & 2,2 \\
\hline $\begin{array}{l}\text { Production of } \\
\text { GDP - } \\
\text { Information and } \\
\text { communication } \\
\text { (percent) }\end{array}$ & 1,9 & 1,6 & 1,7 & 1,7 & 1,8 & 2,0 & 1,8 & 1,6 & 1,6 \\
\hline $\begin{array}{l}\text { Production of } \\
\text { GDP - Financial } \\
\text { and insurance } \\
\text { activities }\end{array}$ & 1,2 & 1,4 & 2,0 & 2,2 & 2,6 & 2,9 & 2,6 & 2,2 & \\
\hline
\end{tabular}




\begin{tabular}{|c|c|c|c|c|c|c|c|c|c|}
\hline (percent) & & & & & & & & & \\
\hline $\begin{array}{l}\text { Production of } \\
\text { GDP -Real } \\
\text { estate activities } \\
\text { (percent) }\end{array}$ & 1,6 & 1,6 & 1,8 & 2,1 & 2,5 & 3,4 & 3,1 & 3,0 & \\
\hline $\begin{array}{l}\text { Production of } \\
\text { GDP - } \\
\text { Professional, } \\
\text { scientific and } \\
\text { technical } \\
\text { activities } \\
\text { (percent) }\end{array}$ & 1,0 & 1,1 & 1,2 & 1,4 & 1,4 & 1,5 & 1,4 & 1,5 & \\
\hline $\begin{array}{l}\text { Production of } \\
\text { GDP - } \\
\text { Administrative } \\
\text { and support } \\
\text { service activities } \\
\text { (percent) }\end{array}$ & 0,5 & 0,5 & 0,5 & 0,6 & 0,7 & 0,7 & 0,6 & 0,6 & \\
\hline $\begin{array}{l}\text { Production of } \\
\text { GDP -Public } \\
\text { administration } \\
\text { and defense, } \\
\text { social security } \\
\text { (percent) }\end{array}$ & 2,0 & 2,2 & 2,3 & 2,5 & 2,8 & 3,1 & 2,9 & 2,9 & \\
\hline $\begin{array}{l}\text { Production of } \\
\text { GDP -Education } \\
\text { (percent) }\end{array}$ & 3,4 & 3,1 & 3,1 & 3,3 & 3,3 & 3,6 & 3,1 & 2,8 & \\
\hline $\begin{array}{l}\text { Production of } \\
\text { GDP -Human } \\
\text { health and social } \\
\text { work activities } \\
\text { (percent) }\end{array}$ & 1,6 & 1,4 & 1,7 & 1,8 & 1,9 & 2,1 & 1,8 & 1,6 & \\
\hline $\begin{array}{l}\text { Production of } \\
\text { GDP -Arts, } \\
\text { entertainment } \\
\text { and recreation } \\
\text { (percent) }\end{array}$ & 0,7 & 0,7 & 0,8 & 0,9 & 1,0 & 1,1 & 0,9 & 0,9 & \\
\hline $\begin{array}{l}\text { Production of } \\
\text { GDP -Other } \\
\text { service activities } \\
\text { (percent) }\end{array}$ & 1,0 & 0,8 & 0,9 & 1,0 & 1,1 & 1,2 & 1,1 & 1,1 & \\
\hline $\begin{array}{l}\text { Production of } \\
\text { GDP - Total } \\
\text { (percent) }\end{array}$ & 93,2 & 94,1 & 93,8 & 93,3 & 92,5 & 91,0 & 91,8 & 92,9 & 92,2 \\
\hline
\end{tabular}




\section{Source:}

https://www.azstat.org/portal/tblInfo/TblInfoList.do\#994_010, [Accessed: 20 October 2019]

Average annual changes in production of the GDP from 1999 to 2009 in Table 4 show the slight changes in production from 1999 to 2009.

Table 4. Average annual changes in production of the GDP from 1999 to 2009

\begin{tabular}{|l|l|}
\hline Indicator & $\begin{array}{l}\text { Average annual changes in } \\
\text { production of the GDP from } \\
1999 \text { to 2009 } \\
(\%)\end{array}$ \\
\hline $\begin{array}{l}\text { Production of GDP - Agriculture, } \\
\text { hunting and forestry (annual, \%) } \\
\text { (percent) }\end{array}$ & 10,30 \\
\hline $\begin{array}{l}\text { Production of GDP - Fishing, fish- } \\
\text { breeding (annual, \%) (percent) }\end{array}$ & 0,26 \\
\hline $\begin{array}{l}\text { Production of GDP - Mining and } \\
\text { quarrying (annual, \%) (percent) }\end{array}$ & 35,55 \\
\hline $\begin{array}{l}\text { Production of GDP - Manufacturing } \\
\text { (annual, \%) (percent) }\end{array}$ & 6,37 \\
\hline $\begin{array}{l}\text { Production of GDP - Production and } \\
\text { distribution of electricity, gas and } \\
\text { water (annual, \%) (percent) }\end{array}$ & 1,50 \\
\hline $\begin{array}{l}\text { Production of GDP - Construction } \\
\text { (annual, \%) (percent) }\end{array}$ & 8,62 \\
\hline $\begin{array}{l}\text { Production of GDP - Wholesale and } \\
\text { retail trade, repair of motor vehicles, } \\
\text { motorcycles and personal and household } \\
\text { goods (annual,\%) (percent) }\end{array}$ & 6,39 \\
\hline $\begin{array}{l}\text { Production of GDP - Hotels and } \\
\text { restaurants (annual, \%) (percent) }\end{array}$ & 0,53 \\
\hline $\begin{array}{l}\text { Production of GDP - Transport, storage } \\
\text { and communication (annual, \%) } \\
\text { (percent) }\end{array}$ & 9,00 \\
\hline $\begin{array}{l}\text { Production of GDP - Financial } \\
\text { intermediation (annual, \%) (percent) }\end{array}$ & 1,24 \\
\hline
\end{tabular}




\begin{tabular}{|l|l|}
\begin{tabular}{|l|l|} 
Production of GDP - Real estate, renting \\
and business activities (annual, \%)
\end{tabular} & \\
\begin{tabular}{l} 
(percent) \\
\hline $\begin{array}{l}\text { Production of GDP Public } \\
\text { administration and defense: social }\end{array}$
\end{tabular} & 2,38 \\
\begin{tabular}{l} 
security (annual, \%) (percent) \\
\hline $\begin{array}{l}\text { Production of GDP - Education (annual, } \\
\text { \%) (percent) }\end{array}$
\end{tabular} & 3,65 \\
\hline $\begin{array}{l}\text { Production of GDP - Health and social } \\
\text { work (annual, \%) (percent) }\end{array}$ & 1,54 \\
\hline $\begin{array}{l}\text { Production of GDP - Other community, } \\
\text { social and personal service activities } \\
\text { (annual, \%) (percent) }\end{array}$ & 2,58 \\
\hline $\begin{array}{l}\text { Production of GDP - FISIM (annual, \%) } \\
\text { (percent) }\end{array}$ & $-0,78$ \\
\hline $\begin{array}{l}\text { Production of GDP - Total- (annual, \%) } \\
\text { (percent) }\end{array}$ & 94,27 \\
\hline $\begin{array}{l}\text { Source: Author } \\
\text { https://www.azstat.org/portal/tblinfo/TblinfoList.do\#994_010, }\end{array}$ \\
\hline
\end{tabular}

Table 4 shows that the biggest annual average growth of $35,55 \%$ is based on mining and quarrying, followed by agriculture, hunting and forestry $10,30 \%$, transport, storage and communication $9,0 \%$, and construction $8,62 \%$. The changes are slow, ineffective and require strategic changes in the economy of the government, more FDI and far more effective inclusions of other international modes for foreign investment including franchise. Even some sources, such as OECD (2019), Quartz (2018), Forbes (2019) and Azerbaijan official web sites (2019), show evidence of huge effort of Azerbaijan's government to modernize and restructure the economy, especially mining and oil sectors.

The above figures approve the first hypothesis that an effective development and growth of the economy measured by GDP should be increased through the industry sectors other than mineral fuels, minerals oils and their distillation products.

As a result of the economic downturn, Azerbaijan began a program to diversify its economy, targeting the agriculture, regional transportation, 
tourism, and information/communication technology (ICT) sectors. For this purpose, the "Strategic Road Map on National Economy and Key Sectors of the Economy of Azerbaijan" was adopted and approved by the Decree №1138 signed by the President of the Republic of Azerbaijan Mr. Ilham Aliyev on December 06, 2016. The government heavily subsidizes machinery and other agricultural inputs, targeting hazelnuts, rice, citrus fruits, tea, tobacco, and cotton. Azerbaijan has also launched a series of projects to develop north-south and east-west trade and transit corridors to turn the Port of Alat and the adjacent Free Trade Zone (FTZ) into regional logistics hubs. To promote tourism, the government has waived visa requirements for several countries and simplified the application process. The government has also created several high tech parks as part of its efforts to bolster the ICT sector.

Despite this progress, oil and gas are still the primary economic drivers and directly account for $44 \%$ of Azerbaijan's GDP and more than $90 \%$ of exports, but only 5\% of the employment. In June 2018, President Aliyev formally inaugurated the Southern Gas Corridor (SGC) with a "first gas" ceremony drawn from the second phase development of the Shah Deniz offshore gas field. First deliveries to Italy via the Trans-Anatolian Pipeline (TANAP) and the Trans-Adriatic Pipeline (TAP) are likely to begin in 2020/2021.

\section{The main partners in import and export by industry groups}

Table 5 shows the main Azerbaijan export and import partners. The main partners for exports are Italy, with three times larger exports than Turkey, and then comes Israel, with eight time less export than Italy, followed by Russia and Czech Republic. Partners for imports are Russia, Turkey, China, USA and Ukraine. The neighboring countries such as Iran, Georgia, Kazakhstan, as well as other CIS countries (except Armenia) also play a significant role in trade relations of Azerbaijan. Despite moderate import from USA, which is twice less than Russia and Turkey, the largest number of franchises which operates in Azerbaijan is coming from USA. Export (2019) underlines that franchising can be a successful retail model in Azerbaijan, and several well-known brands from USA, Europe, and Turkey operate in the country.https://www.export.gov/article?id=AzerbaijanFranchising [Accessed: 16 September 2019] 
Still, there are some mismatch between current export and import figures and existing franchise operations in Azerbaijan.

Table 5. Azerbaijan export and import data for 2017 in \%

\begin{tabular}{|l|l|l|l|}
\hline \multicolumn{2}{|l|}{ Export } & Import \\
\hline Italy & $31,9 \%$ & Russia & $16,8 \%$ \\
\hline Turkey & $9,9 \%$ & Turkey & $14,7 \%$ \\
\hline Israel & $4,6 \%$ & China & $11,2 \%$ \\
\hline Russia & $4,3 \%$ & United States & $8,3 \%$ \\
\hline Czech Republic & $4,0 \%$ & Ukraine & $5,5 \%$ \\
\hline
\end{tabular}

Source: Azerbaijan - Market profile, available at http://chinatrade-research.hktdc.com/business-news/article/The-Belt-and-RoadInitiative/Azerbaijan-Market-

Profile/obor/en/1/1X000000/1X0A3IH1.htm, [Accessed: 20 October 2019]

Azerbaijan export by groups shows huge export supremacy of the mineral fuels group, mineral oils and products of their distillation, or an average of $91.62 \%$ for the observed period, while other groups occupy less than $1 \%$ on average, and the edible fruit group and nuts, peel of melons averaged $1.46 \%$ over the period under review. All this gives a franchise opening space that would increase with participation of other gaps, over the dominant mineral fuels group, minerals oils and their distillation products. See Table 6.

Table 6. Azerbaijan export by groups in \%

\begin{tabular}{|l|l|l|l|l|l|l|}
\hline \multirow{2}{*}{ Group } & \multicolumn{6}{|l|}{ Export by group in \% } \\
\cline { 2 - 7 } & 2013 & 2014 & 2015 & 2016 & 2017 & 2018 \\
\hline $\begin{array}{l}\text { Edible vegetables and } \\
\text { certain roots and } \\
\text { tubers (thsd. USD \$) }\end{array}$ & 0,32 & 0,5 & 0,7 & 1,0 & 1,4 & 1,20 \\
\hline $\begin{array}{l}\text { Edible fruit and nuts, } \\
\text { peel of melons (thsd. } \\
\text { USD \$) fats and }\end{array}$ & 0,73 & 0,9 & 1,8 & 1,8 & 1,9 & 1,68 \\
\hline $\begin{array}{l}\text { Animal } \\
\text { vegetable oils (thsd. } \\
\text { USD \$) }\end{array}$ & 0,96 & 0,9 & 1,2 & 0,1 & 0,1 & 0,09 \\
\hline
\end{tabular}




\begin{tabular}{|l|l|l|l|l|l|l|}
$\begin{array}{l}\text { Sugars and sugar } \\
\text { confectionery (thsd. } \\
\text { USD \$) }\end{array}$ & 1,02 & 1,0 & 1,7 & 0,5 & 0,3 & 0,13 \\
\hline $\begin{array}{l}\text { Mineral fuels, } \\
\text { minerals oils and } \\
\text { products of their } \\
\text { distillation (thsd. USD } \\
\text { \$) }\end{array}$ & 93,43 & 93,3 & 89,4 & 91,2 & 90,5 & 91,92 \\
\hline $\begin{array}{l}\text { Plastic and articles } \\
\text { thereof (thsd. USD \$) }\end{array}$ & 0,51 & 0,7 & 0,9 & 0,7 & 0,7 & 0,61 \\
\hline $\begin{array}{l}\text { Pearls, precious } \\
\text { stones, precious } \\
\text { metals, and articles } \\
\text { thereof (thsd. USD \$) }\end{array}$ & 0,31 & 0,4 & 0,7 & 0,6 & 0,9 & 0,61 \\
\hline
\end{tabular}

Source: Author calculations based

https://www.azstat.org/portal/tblInfo/TblInfoList.do\#994 010,

[Accessed: 26 October 2019]

To increase the process of modernization, restructuring and diversification of the economy in Azerbaijan, it is desirable to open franchise facilities (food and beverage areas) along the routes of the three main roads leading from Baku to Iran by route E002: Baku to Georgia by route E60, and Baku to Russia by route E119 and in the main airports. See Maps 1 and 2.

Map 1. Airports in Azerbaijan

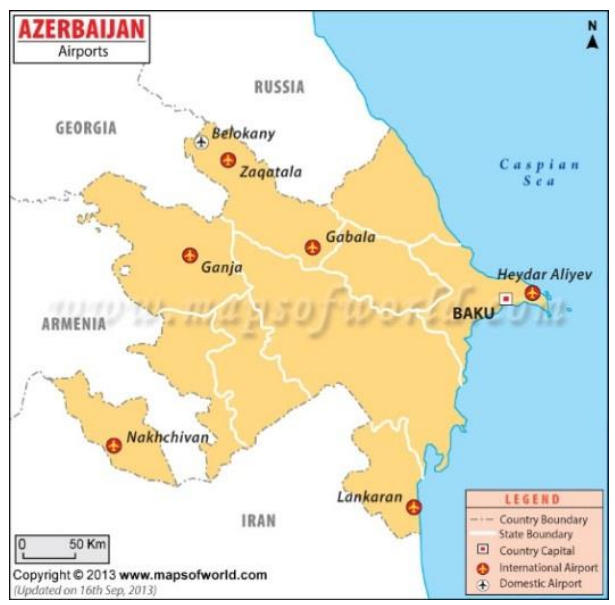

Map 2. The main roads in Azerbaijan

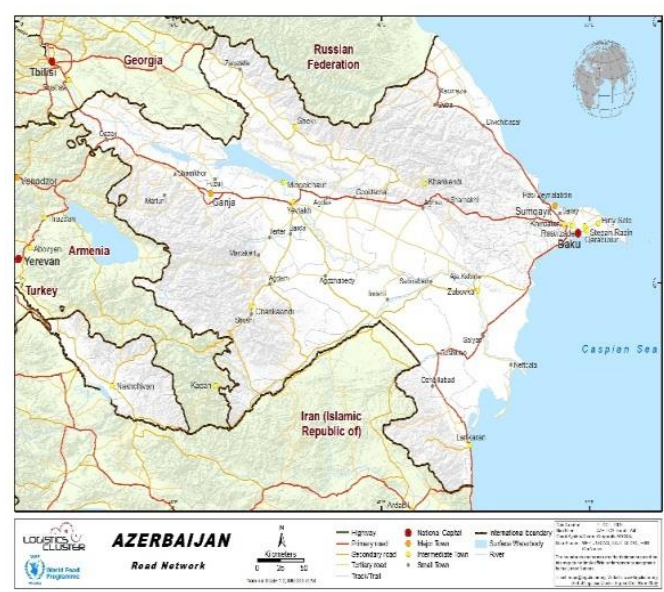


Source: Azerbaijan travel images, available at http://www.travelimages.com/az-maps.html, [Accessed: 20 October 2019]

\section{5 .Population of Azerbaijan as a main driver for franchise opportunities}

Size of the country, economic growth and stability, high employment, low inflation, stable prices, disposable income, and especially the purchasing power of the people are the main factors that attract franchises. The population size and density within Azerbaijan are very different. The region Baku city has the highest population density, approximately seven times higher than the Absheron region and approximately eleven times higher than the Ganja-Qazakh and Aran regions. Azerbaijan possesses relatively good networks of roads along these regions. As mentioned above, the highest percentage of natural gas production is in these four regions. However, the average monthly nominal wages, with the exception of Baku City, are not higher in these regions.

Table 7. Population density by region in Azerbaijan in 2018

\begin{tabular}{|l|l|l|}
\hline $\begin{array}{l}\text { Economic } \\
\text { region code }\end{array}$ & $\begin{array}{l}\text { Economic region } \\
\text { names }\end{array}$ & $\begin{array}{l}\text { Population density by } \\
\text { region in Azerbaijan } \\
\text { in 2018 }\end{array}$ \\
\hline 01 & Absheron & 154 \\
\hline 06 & Aran & 96 \\
\hline 00 & Baku city & 1064 \\
\hline 09 & Daglig-Shirvan & 52 \\
\hline 02 & Ganja-Qazakh & 104 \\
\hline 08 & Kalbajar-Lachin & 40 \\
\hline 04 & Lankaran & 154 \\
\hline 10 & Nakhchivan & 83 \\
\hline 05 & Quba-Khachmaz & 79 \\
\hline 03 & Sheki-Zaqatala & 70 \\
\hline 07 & Yukhari-Karabakh & 93 \\
\hline
\end{tabular}

Source: Population density by region in Azerbaijan 2018 available at https://www.azstat.org/portal/tblInfo/TblInfoList.do\#994 010, [Accessed: 20 October 2019] 
Using the figures displayed in Table 8, the correlation coefficient (connection, dependence) calculated as the relationship and dependence between the population per region, and the average monthly nominal wage (Euro) was $r=0,57$. That means that the association is direct and moderate, i.e. an increase in population leads to a moderate increase in average monthly nominal wages. Thus, average income earned in the main oil regions has no strong correlation to the employees' earned incomes. Graph 1 better presents the average monthly nominal wages across the regions.

Table 8. Population and average monthly nominal wages (EUR) in the year 2018 by regions

\begin{tabular}{|l|l|l|l|}
\hline $\begin{array}{l}\text { Economic } \\
\text { region } \\
\text { code }\end{array}$ & Economic region names & $\begin{array}{l}\text { Average } \\
\text { monthly } \\
\text { nominal wages } \\
\text { - EUR - 2018 }\end{array}$ & $\begin{array}{l}\text { Population } \\
\text { in 000 - } \\
2018\end{array}$ \\
\hline 01 & Absheron & 215,49 & 572,6 \\
\hline 06 & Aran & 161,91 & 2025,8 \\
\hline 00 & Baku city & 420,69 & 2277,5 \\
\hline 09 & Daglig-Shirvan & 163,56 & 318,6 \\
\hline 02 & Ganja-Qazakh & 176,57 & 1284,2 \\
\hline 08 & Kalbajar-Lachin & 176,68 & 256,7 \\
\hline 04 & Lankaran & 161,96 & 937,2 \\
\hline 10 & Nakhchivan & 230,84 & 456,1 \\
\hline 05 & Quba-Khachmaz & 176,41 & 549,4 \\
\hline 03 & Sheki-Zaqatala & 153,70 & 621,4 \\
\hline 07 & Yukhari-Karabakh & 157,06 & 682 \\
\hline \multicolumn{4}{|c|}{ Author calculations } \\
Source: $:$
\end{tabular}


Graph 1. Population and average monthly nominal wages (EUR) in the year 2018 by regions

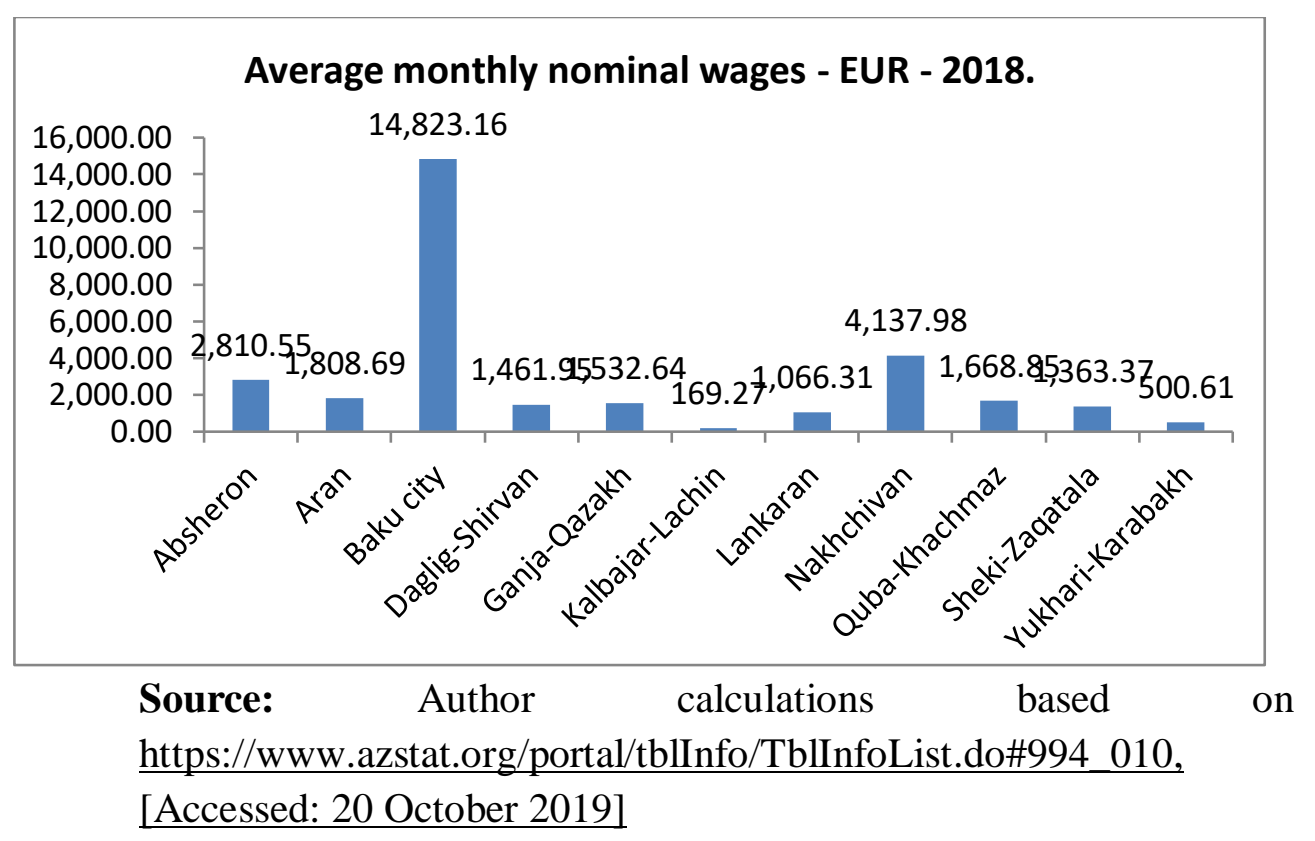

The correlation coefficient for output of goods and services in the main sectors of economy, per capita and population is $r=0,65$, which shows a moderate direct dependence, i.e. outputs of goods and services in the main sectors of the economy, per capita by region increases moderately with the increase in population per region. Thus, the main conclusion is that production sector which is dominated by mining and quarrying must be diversified in service and tertiary sector activities such as digitalization, ecommerce and e-business; small enterprise sectors - SMEs; Computer \& IT; Tourism and Travel; Real Estate.

Table 9. Output of goods and services in the main sectors of economy, per capita in EUR and population in the regions in the year 2018

\begin{tabular}{|l|l|l|l|}
\hline $\begin{array}{l}\text { Economic } \\
\text { region } \\
\text { code }\end{array}$ & $\begin{array}{l}\text { Economic region } \\
\text { names }\end{array}$ & $\begin{array}{l}\text { Output of goods } \\
\text { and services in } \\
\text { main sectors of } \begin{array}{l}\text { of } \\
\text { economy, per } \\
\text { capita EUR - 2018 }\end{array}\end{array}$ & $\begin{array}{l}\text { Population } \\
\text { in }\end{array}$ \\
\hline 01 & Absheron & 2018 \\
\hline 06 & Aran & $1.810,55$ & 572,6 \\
\hline 00 & Baku city & $14.823,16$ & 2025,8 \\
\hline
\end{tabular}




\begin{tabular}{|l|l|l|l|}
09 & Daglig-Shirvan & $1.461,95$ & 318,6 \\
\hline 02 & Ganja-Qazakh & $1.532,64$ & 1284,2 \\
\hline 08 & Kalbajar-Lachin & 169,27 & 256,7 \\
\hline 04 & Lankaran & $1.066,31$ & 937,2 \\
\hline 10 & Nakhchivan & $4.137,98$ & 456,1 \\
\hline 05 & Quba-Khachmaz & $1.668,85$ & 549,4 \\
\hline 03 & Sheki-Zaqatala & $1.363,37$ & 621,4 \\
\hline 07 & Yukhari-Karabakh & 500,61 & 682 \\
\hline
\end{tabular}

Source: $\quad$ Author calculations based on https://www.azstat.org/portal/tblInfo/TblInfoList.do\#994_010, [Accessed: 20 October 2019]

Graph 2. Age population projection in the year 2018 by region

Source: Author calculations based on https://www.azstat.org/portal/tblInfo/TblInfoList.do\#994_010, [Accessed: 20 October 2019]

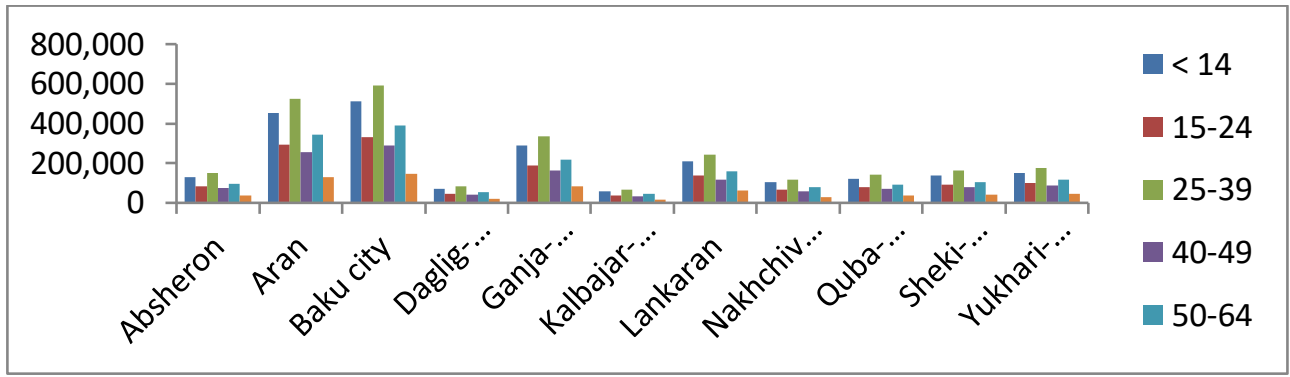

The attractiveness of the possible new franchises is important because these regions are dominated by population aged 25-39 years old. See Graphs 2 and 3 .

Graph 3. Total population by groups in 2018 


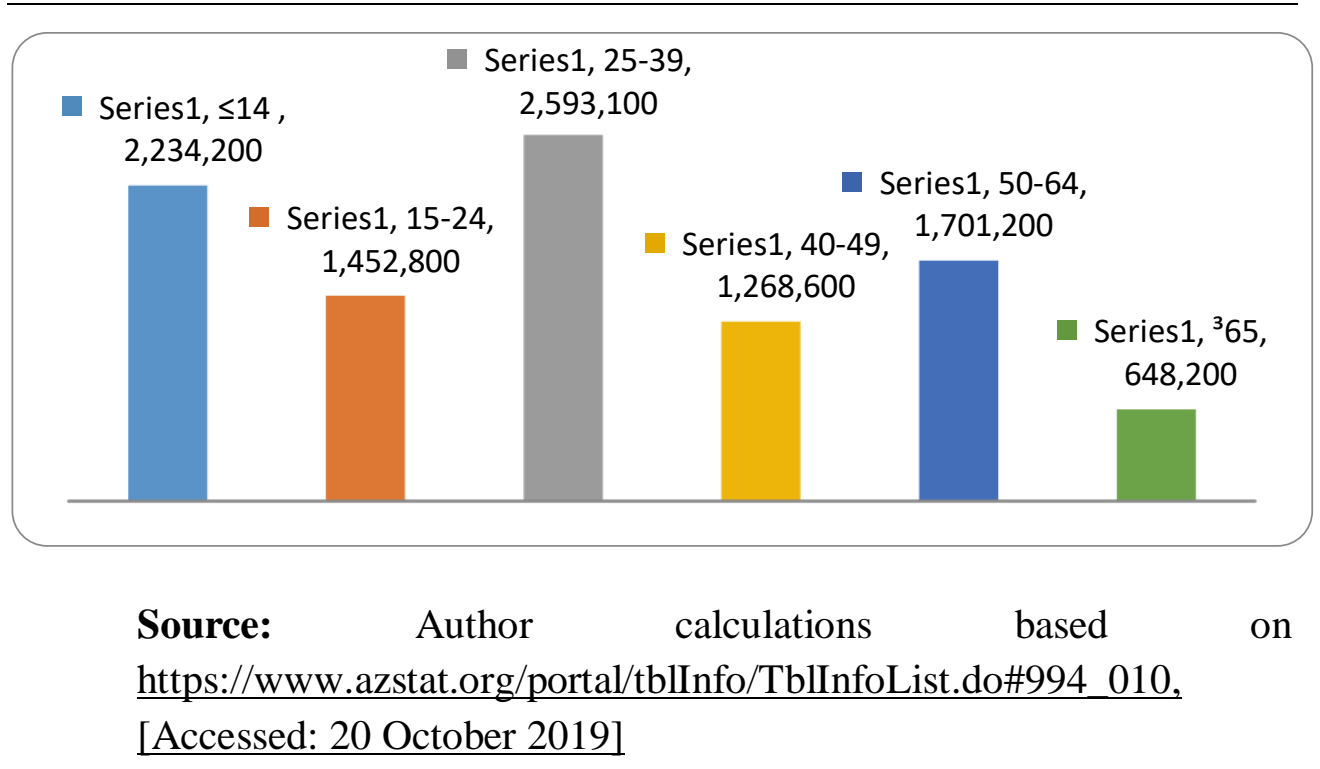

\section{Structural changes and diversification of the economy of Azerbaijan by franchises operations}

Export (2019), the official USA agency to help USA companies to export, states that "...As a result of the economic downturn, Azerbaijan began a program to diversify its economy, targeting the agriculture, regional transportation, tourism, and information/communication technology (ICT) sectors ... Azerbaijan has also launched a series of projects to develop north-south and east-west trade and transit corridors to turn the Port of Alat and the adjacent Free Trade Zone (FTZ) into regional logistics hubs ...The government has also created several high-tech parks as part of its efforts to bolster the ICT sector.

Despite this progress, which can be seen in the Tables and Graphs above, oil and gas are the primary economic drivers and directly account for $44 \%$ of Azerbaijan's GDP and more than $90 \%$ of exports, but only $5 \%$ of employment. Thus, this must be changed. In the last two years, the economy of Azerbaijan continued to improve after recovering from crisis in 2015. Low world oil prices, from 2014 to 2016, hit Azerbaijan's economy hard, resulting in two currency devaluations in 2015, high inflation in 20162017, and the closure of several banks.

The above Tables, Figures and Graphs show why Azerbaijan needs to restructure and diversify its economy, targeting the agriculture, regional transportation, tourism, and information/communication technology (ICT) sectors. This huge task, with which the country is facing now, can be carried out by franchises. One of unused opportunities is franchises in food alongside roads and airports. Probably, food franchise can be used as the benchmark food in other franchise opportunities. Table 10 shows a total of 
285 franchises in food in Azerbaijan and that $41.75 \%$ of them have an investment of $\$ 200,000$ to $\$ 500,000$.

Table 10. Number of food franchises by the size of investment

\begin{tabular}{|l|l|}
\hline Investment & Number \\
\hline$<5000$ & 2 \\
\hline $5000-10000$ & 4 \\
\hline $10000-20000$ & 5 \\
\hline $20000-50000$ & 15 \\
\hline $50000-100000$ & 23 \\
\hline $100000-200000$ & 68 \\
\hline $200000-500000$ & 119 \\
\hline$>500000$ & 49 \\
\hline Total & 285 \\
\hline
\end{tabular}

Source: Author calculations based on Franchise opportunities in Azerbaijan, available at https://topfranchise.com/international-franchiseopportunities/european/franchises-in-azerbaijan/ , [Accessed: 20 October 2019] For example, the most famous brand McDonalds (recently celebrated 20 years of presence in Azerbaijani market) has 16 facilities in Azerbaijan, of which 15 are in Baku and one in Ganja. For this reason, it is not possible to create any mathematical model by which it would be possible to predict the number of objects in terms of population and average income/earnings in a particular region/city to justify the completion of a new object. The other popular brand, Starbucks, operates in Azerbaijan on four locations and all of them are in Baku. As for the number of other franchises, in Computer \& IT Sector Azerbaijan operates 7 franchises, in Travel 22, in Real Estate 12, and in Manufacturing 13 franchises. For more information, see Topfranchise (2019).As can be seen, a small number of franchises operate in a very concentrated level in Baku, but unlimited opportunities are shown in other regions, cities, airports and alongside strategic routes and towards Iran, Turkey and Russia.

A lot of online franchise associations and organizations show richness of different choices, by industry sector or specific activities and size of potential investments. Thus, this is a great opportunity for the country to modernize and change its future. Blog hubspot (2019) shows 39 Best Franchise Opportunities to Buy and Own in 2019. The range of possible franchises is listed by different criteria: (1) Best franchise to buy; (2) Low cost/cheap franchises - develop entrepreneurship process, SMEs and create 
effective supply chain network for largest businesses; (3) Best franchises to open and own; (4) Most profitable franchises, available at https://blog.hubspot.com/sales/franchise-opportunities, [Accessed:17

September 2019]

\section{Conclusion}

The Republic of Azerbaijan is a huge potential for franchise investments, as a modern business form of international financing, given the very small percentage of the franchise's share in the total turnover of the country. For franchising to be the basic way of entrepreneurial investment, it is necessary to ensure an adequate market climate accompanied by appropriate legislation and the necessary enforcement institutions. A previous analysis has indicated that areas that could be a potential destination for investment must be considered. Population has proven to be a significant factor in business decision making. In less populated areas it is justified to open franchises if they are in high-frequency locations such as highways or tourist destinations visited by many domestic and elderly tourists or persons in transit. It is also very important to emphasize that for management, in addition to all the indicators analyzed, it is very important to maintain standards that include recognizable looks, standard quality offer, welltrained staff and everything else the brand carries with it.

\section{Disclosure statement}

No potential conflict of interest was reported by the author.

\section{Contact Information}

E-mail: hasanov@gmail.com 


\section{References and notes:}

Bisio, R. (2008) The Educated Franchisee: The How-To Book for Choosing a Winning Franchise. Minneapolis: Bascom Hill Publishing Group.

Duhigg, C. (2017) Smarter Faster Better: The Transformative Power of Real Manhattan: Productivity. Random House Trade Paperbacks.

Grossmann, R. \& Katz, J.M. (2017) Franchise Bible: How to Buy a Franchise or Franchise Your Own Business. Irvine: Entrepreneur Press.

Hayes, P. J. (2013) 101 Questions to ask before you invest in a Franchise. London: Kindle edition.

Maillet, W. (2014) Franchising Demystified: The Definitive Franchise Handbook. Victoria: Friesen Press.

Martuza, M. (2014) The Franchise Rules: How To Find A Great Franchise That Fits Your Goals, Skills and Budget. London: Kindle book.

Miller, C. (2017) Brick \& Mortar Franchise Success: Know the Costs or Pay the Price. Scotts Valley: Create Space Independent Publishing Platform.

Seid, M. \& Thomas, D. (2016) Franchising for Dummies, $2^{\text {nd }}$ edition. London: John Wiley and Sons Ltd.

Brown, H. (1969), Franchising, Trap for Trusting, Boston: Appendix A.

ASIS Azerbaijan's Statistics, available at https://www.azstat.org/portal/tblInfo/TblInfoList.do, [Accessed: 20 October 2019]

The impact of franchising on development, available at http://www.scielo.org.mx/pdf/prode/v49n193/0301-7036-prode-49-193-95-en.pdf [Accessed: 20 October 2019]

Franchises Drive Job and Economic Growth, available at https://www.forbes.com/sites/jeffbevis/2019/03/27/franchises-drive-job-andeconomic-growth/\#6d77e5677bb0 [Accessed: 17 September 2019]

Macrotrends, Azerbaijan GDP Per Capita 1990-2019, available at https://www.macrotrends.net/countries/AZE/azerbaijan/gdp-per-capita,[Accessed: 20 October 2019]

OECD, Better polices for better lives, available at https://www.oecd.org/about/members-andpartners/, [Accessed: 20 October 2019]National economic impact of Franchising, available at https://franchiseeconomy.com [Accessed: 17 September 2019]

Global franchising in emerging and transitioning economies, available at https://www.researchgate.net/publication/236984260_Global_franchising_in_emergin $\mathrm{g}$ and transitioning_economies/link/0c96052819d68ae3bd000000/download [Accessed: 17 September 2019]

How to Transition to Franchise Ownership, available at https://www.forbes.com/sites/jeffbevis/2019/05/24/how-to-transition-to-franchiseownership/\#3f901406eb4b [Accessed: 20 October 2019]

Azerbaijan: Market Profile, available at http://china-trade-research.hktdc.com/businessnews/article/The-Belt-and-Road-Initiative/Azerbaijan-Market-

Profile/obor/en/1/1X000000/1X0A3IH1.htm [Accessed: 17 September 2019]

UK at centre of secret $\$ 3$ bn Azerbaijani money laundering and lobbying scheme, available at https://www.theguardian.com/world/2017/sep/04/uk-at-centre-of-secret-3bnazerbaijani-money-laundering-and-lobbying-scheme [Accessed: 17 September 2019]

Franchise Opportunities in Azerbaijan, available at https://topfranchise.com/international-franchiseopportunities/european/franchises-in-azerbaijan/ [Accessed: 17 September 2019]

Statista Logo, available at https://www.statista.com/statistics/457501/gross-domestic-product-gdpper-capita-in-azerbaijan/

Exportgov logo, Azerbaijan Country Commercial Guide, available at $\underline{\text { https://www.export.gov/article?id=Azerbaijan-Market-Overview }} \quad, \quad$ [Accessed: $\underline{20}$ October 2019]

Hub Spot, available at https://blog.hubspot.com/sales/franchise-opportunities, [Accessed: 20 October 2019]

Quartz, The countries with the most Starbucks locations, available at https://qz.com/1536009/thecountries-with-the-most-starbucks-locations/, [Accessed: 20 October 2019]

Azerbaijan travel images, available at http://www.travel-images.com/az-maps.html 